\title{
PENGARUH MODEL TALKING STICK TERHADAP HASIL BELAJAR PKn PADA SISWA KELAS V SEMESTER II SD DI GUGUS I KECAMATAN GEROKGAK
}

\author{
I.G.M.P. Utama ${ }^{1}$, I.K. Dibia ${ }^{2}$, N.T. Renda ${ }^{3}$ \\ 1,2,3 Jurusan PGSD, Universitas Pendidikan Ganesha, Singaraja \\ e-mail: pandita.utama@gmail.com, \\ 1iketut.dibia@undiksha.ac.id, ${ }^{2}$ ndaratanggu.renda@undiksha.ac.id
}

\begin{abstract}
Abstrak
Penelitian ini bertujuanuntuk mengetahui perbedaan yang signifikan hasil belajar PKn antara siswa yang dibelajarkan dengan model Talking Stick dan siswa yang dibelajarkan dengan pembelajaran konvensional pada siswa kelas V semester II SD di Gugus I Kecamatan Gerokgak. Penelitian ini merupakan penelitian eksperimen semu dengan rancangan post test only control grup design. Populasi penelitian ini adalah seluruh kelas V SD di Gugus I Kecamatan Gerokgak dengan jumlah total 126 siswa. Sampel diambil dengan teknik random sampling sehingga diperoleh kelas V SD Negeri 3 Tukadsumaga sebagai kelompok eksperimen dan kelas V SD Negeri 1 Tukadsumaga sebagai kelompok kontrol. Instrumen pengumpulan data yang digunakan dalam penelitian ini adalah tes objektif hasil belajar PKn. Data dianalisis menggunakan statistik deskriptif dan Independent sample t-tes. Hasil penelitian menunjukan bahwa terdapat perbedaan yang signifikan pada hasil belajar PKn antara siswa yang belajar dengan model Talking Stick dan siswa yang dibelajarkan dengan pembelajaran konvensional. Besarnya $t_{\text {hitung }}$ adalah 3,048, sedangkan $t_{\text {tabel }}$ pada taraf signifikasi 5\% dan $\mathrm{db}=42$ adalah 2,021. Hal ini berarti $t_{\text {hitung }}>t_{\text {tabel }}$. Adapun rata-rata skor hasil belajar PKn siswa yang belajar dengan model Talking Stick $(23,08)$ lebih tinggi dari siswa yang dibelajarkan dengan pembelajaran konvensional $(19,26)$. Dengan demikian, model model Talking Stick berpengaruh terhadap hasil belajar PKn pada siswa kelas V Semester II di Gugus I Kecamatan Gerokgak Tahun Pelajaran 2017/2018.
\end{abstract}

Kata Kunci:talking stick, hasil belajar PKn

\begin{abstract}
This study aims to find out the significant differences in learning outcomes of Civics among students who were taught by the Talking Stick model and students who were taught by conventional learning in grade $V$ students of second semester of elementary school in Gugus I of Gerokgak Subdistrict. This research is a quasi-experimental research with post test only control group design design. The population of this study is the entire class V SD in the first group of Gerokgak District with a total of 126 students. The sample was taken by random sampling technique so that it was obtained by grade V SD Negeri 3 Tukadsumaga as experiment group and class V SD Negeri 1 Tukadsumaga as control group. The instrument of data collection used in this research is objective test of Civic learning result. Data were analyzed using descriptive statistics and Independent sample t-test. The results showed that there were significant differences in the learning outcomes of Civics between students studying with the Talking Stick model and students who were taught by conventional learning. The magnitude of t_hcount is 3,048, while t_tabel at 5\% significance level and $d b=42$ is 2.021. This means t_count $>$ t_table. In addition, the average score of Civics learning outcomes of students who studied with the Talking Stick model (23.08) was higher than that of students taught by conventional learning $(19,26)$. Thus, Talking Stick model model influences the learning outcomes of Civics in Grade V students of Grade II in Gugus I, Gerokgak Sub District, Lesson Year 2017/2018. Suggestions for further research are expected to result in this research can be reused in other lessons.
\end{abstract}

Keywords: talking stick, Civic learning outcomes 


\section{PENDAHULUAN}

Pendidikan merupakan salah satu aspek yang paling penting dalam pembangunan nasional. Pendidikan bagi bangsa Indonesia yang sedang membangun seperti saat ini merupakan kebutuhan mutlak yang harus dikelola dan dikembangkan dengan baik untuk mencapai tujuan pendidikan di Indonesia. Tujuan tersebut tertuang dalam UndangUndang Republik Indonesia No. 20 tahun 2003 tentang Sistem Pendidikan Nasional Pasal 3 menyatakan untuk berkembangnya potensi peserta didik agar menjadi manusia yang beriman dan bertakwa kepada Tuhan Yang Maha Esa, berakhlak mulia, sehat, berilmu, cakap, kreatif, mandiri, dan menjadi warga negara yang demokratis serta bertanggung jawab". Untuk mencapai tujuan tersebut, harus mendapat perhatian yang serius dari berbagai faktor, seperti guru, peserta didik, kurikulum, serta sarana dan prasarana pendukung pembelajaran.

Untuk mencapai tujuan dari Sistem Pendidikan Nasional tersebut, harus mendapat perhatian serius dari berbagai faktor, seperti guru, siswa, kurikulum serta sarana dan prasarana pembelajaran. Ketentuan mengenai pengembangan kurikulum sebagaimana yang tercantum dalam UU No. 20 Tahun 2003 tentang Sistem Pendidikan Nasional, Pasal 37 Ayat 1 menyebutkan bahwa "kurikulum pada jenjang pendidikan dasar dan menengah wajib memuat 10 mata pelajaran". Pada Sistem Pendidikan Nasional khususnya pada SD diberikan beberapa mata pelajaran salah satunya adalah PKn. Mata pelajaran ini tidak hanya menekankan pada pengembangan intelektual saja, tetapi juga menekankan pada nilai dan moral siswa. Susanto (2013:227) menyatakan bahwapembelajaran PKn di sekolah dasar dimaksudkan sebagai suatu proses belajar mengajar dalam rangka membantu peserta didik agar dapat belajar dengan baik dan membentuk manusia Indonesia seutuhnya dalam pembentukan karakter bangsa yang diharapkan mengarah pada penciptaan suatu masyarakat yang menempatkan demokrasi dalam kehidupan berbangsa dan bernegara yang berlandaskan pada Pancasila, UUD, dan norma-norma yang berlaku di masyarakat yang diselenggarakan selama enam tahun.

Dalam hal ini, para guru diharapkan memahami secara mendalam tentang mata pelajaran PKn, sehingga tidak kesulitan dalam mendesain danmelaksanakan pembelajaran PKn yang bermakna. Guru tentunya harus memiliki keterampilan mendesain pembelajaran seperti menggunakan pendekatan, strategi, model pembelajaran serta metode dengan tepat sehingga pembelajaran PKn yang bermakna dapat tercapai. Namun, kenyataan di lapangan dalam pelaksanaan pembelajaran masih belum mencapai hasil yang diharapkan.

Berdasarkan kegiatan lapangan yang dilakukan melalui wawancara, observasi dan studi dokumen pada tanggal $24 \quad-27$ November 2017 di SD Gugus I Kecamatan Gerokgak khususnya kelas 5 pada mata pelajaran PKn. Hasil wawancara dengan guruguru mengenai model yang digunakan guru ketika melaksanakan pembelajaran PKn di kelas, ternyata guru sering menggunakan metode ceramah dan ketika ditanya mengenai alasan guru sering menggunakan metode ceramah karena guru tidak bisa menggunakan model pembelajaran kooperatif.

Ketika dilanjutkan observasi kepada guru-guru yang melaksanakan pembelajaran PKn kelas V SD di Gugus I Kecamatan Gerokgak, terbukti guru lebih banyak menggunakan cara mengajar ceramah dengan pembelajaran dimulai dari pemberian informasi oleh guru kemudian siswa hanya mendengarkan apa yang dijelaskan oleh guru. Guru memakai fasilitas belajar yang ada, seperti buku teks dan papan tulis. Dari hasil wawancara dan observasi tersebut, dapat mempengaruhi hasil belajar siswa.

Berdasarkan hasil study dokumen yang dilakukan, nilai akhir semester siswa masih belum mencapai KKM 100\%. Artinya bahwa, hasil belajar PKn siswa kelas V semester I SD di Gugus I Kecamatan Gerogak Tahun Pelajaran 2017/2018 masih sangat rendah. Hal ini merupakan suatu masalah yang harus diatasi agar hasil belajar siswa menjadi lebih baik. Untuk itu, solusi yang tepat untuk mengatasi masalah di atas adalah dengan 
menggunakan model pembelajaran yang tepat. Salah satu model yang dapat diterapkan untuk meningkatkan hasil belajar PKn adalah model talking stick, karena model ini menuntut siswa untuk aktif dalam berpendapat dan melatih siswa agar berani berbicara di depan kelas.

Model talking stick merupakan salah satu pembelajaran dengan bantuan tongkat yang mendorong siswa untuk lebih aktif dalam pembelajaran dan berani mengemukakan pendapatnya mengenai materi. Sehingga siswa dapat berfikir aktif dan lebih termotivasi dalam belajar. Dengan penerapan model ini akan menuntut siswa untuk memahami materi yang akan diajarkan, karena dalam kegiatan pembelajaran dengan menggunakan model ini mau tidak mau semua siswa harus menanggapi satu pertanyaan yang telah disiapkan oleh guru. Kelebihan model talking stick yaitu menguji kesiapan peserta didik dalam pembelajaran, melatih peserta didik memahami materi dengan cepat, memacu agar peserta didik lebih giat belajar (belajar dahulu sebelum pelajaran dimulai), dan peserta didik berani mengemukakan pendapat (Shoimin, 2014:199).
Berdasarkan uraian tersebut, penelitian ini bertujuan untuk mengetahui perbedaan yang signifikan belajar PKn antara siswa yang dibelajarkan dengan model pembelajaran Talking Sick dan siswa yang dibelajarkan dengan pembelajaran konvensionalpada siswa kelas V semester II SD di Gugus I Kecamatan Gerokgak Tahun Pelajaran 2017/2018.

\section{METODE PENELITIAN}

Penelitian ini merupakan penelitian eksperimen. Adapun tempat pelaksanaan penelitian ini adalah di SD Gugus I Kecamatan Gerokgak, Kabupaten Buleleng Tahun Pelajaran 2017/2018. Penelitian ini dilaksanakan pada semester II (genap) tahun pelajaran 2017/2018 yang dimulai pada akhir Maret sampai akhir April. Populasi dalam penelitian ini adalah siswa kelas V SD di Gugus I Kecamatan Gerokgak. Jumlah seluruh populasi adalah 126 siswa. Banyaknya populasi dan sebarannya dapat dilihat pada table 1. berikut.

Tabel 1. Data Populasi Penelitian

\begin{tabular}{cc}
\hline Nama Sekolah & JumlahSiswa \\
\hline SD Negeri 1 Tukadsumaga & 19 \\
SD Negeri 2 Tukadsumaga & 31 \\
SD Negeri 3 Tukadsumaga & 25 \\
SD Negeri 4 Tukadsumaga & 35 \\
SD Negeri Celukan bawang & 16 \\
Total 5 SD & 126 siswa \\
\hline
\end{tabular}

Pemilihan sampel dalam penelitian ini menggunakan teknik random sampling yaitu pengambilan sampel anggota populasi secara acak tanpa memperhatikan strata yang ada. Selanjutnya dilakukan uji kesetaraan terhadap 5 sekolah dasar tersebut. Penyetaraan sampel dihitung berdasarkan nilai Ulangan Akhir Semester kelas V Semester I pada mata pelajaran PKn tahun pelajaran 2017/2018. Untuk menghitung kesetaraan kelompok sampel digunakan rumus uji ANAVA. Setelah memperoleh hasil perhitungan uji kesetaraan, selanjutnya kelima SD itu dirandom untuk menentukan kelas eksperimen dan kelas kontrol. Dalam pemilihan kelas eksperimen dan kelas kontrol dilakukan dengan teknik random sampling. Hasil dari kelas yang di random adalah SD Negeri 3 Tukadsumaga yang berjumlah 25 orang sebagai kelas eksperimen yang diberikan perlakuan berupa model talkingstick dan SD Negeri 1 Tukadsumaga yang berjumlah 19 orang sebagai kelas kontrol yang diberikan perlakuan berupa pembelajaran konvensional. Instrumen pengumpulan data yang digunakan dalam penelitian ini adalah berupa tes objektif. Soal objektif yang digunakan terdiri dari 30 butir soal. Untuk menentukan butir 
soal instrumen tersebut layak untuk diberikan terhadap kelompok sampel terlebih dahulu dilakukan uji coba. Uji coba tes hasil belajar PKn meliputi: validitas butir tes, reliabilitastes tes, daya beda tes, dan tingkat kesukaran tes. Analisis data dalam penelitian ini dilakukan dalam tiga tahap. Pada tahap pertama dilakukan analisis deskriptif, tahap kedua digunakan analisis uji coba prasyarat untuk pembuktian persyaratan analisis statistik. Sedangkan pada tahap ketiga dilakukan analisis untuk pembuktian hipotesis. Pengujian terhadap hipotesis penelitian yang telah dirumuskan dilakukan melalui metode statistika, hipotesis pertama dilakukan dengan menggunakan analisis Uji Independent Sample t-test. Sebelum dilakukan uji hipotesis terlebih dahulu dilakukan uji prasyarat analisis yang meliputi uji normalitas sebaran data, uji homogenitas varians. Berdasarkan uji prasyarat analisis data, diperoleh bahwa data hasil belajar PKn siswakelompok eksperimen dan kontrol adalah normal dan homogen. Setelah diperoleh hasil uji prasyarat analisis data, dilanjutkan dengan pengujian hipotesis penelitian. Pengujian hipotesis tersebut dilakukan menggunakan independent sample t-test (tidak berkorelasi) dengan rumuspolled varians. Kriterianya, $\mathrm{H}_{0}$ ditolak jika $\mathrm{t}_{\text {hitung }}>$ $\mathrm{t}_{\text {tabel. }}$.

\section{HASIL DAN PEMBAHASAN Hasil}

Hasil penelitian ini menunjukan bahwa terdapat perbedaan hasil belajar PKn antara siswa yang dibelajarkan dengan model Talking Stick dan siswa yang dibelajarkan dengan pembelajaran konvensional pada siswa kelas V semester II SD di Gugus I Kecamatan Gerokgak tahun pelajaran 2017/2018. Sampel penelitian adalah siswa kelas V SD Negeri 3 Tukadsumaga sebagai kelas eksperimen dan siswa kelas V SD Negeri 1 Tukadsumaga sebagai kelas kontrol. Hal ini dapat dilihat dari hasil belajar PKn yang dicapai oleh siswa. Hasil analisis statistik deskriptif data penelitian ini disajikan pada tabel 2 .

Tabel 2. Analisis Data dengan Statistik Deskriptif

\begin{tabular}{ccc}
\hline Mean & 24,03 & 20,08 \\
\hline Median & 24,55 & 20 \\
Modus & 26,21 & 19,83 \\
Standar Deviasi & 4,33 & 3,61 \\
Varians & 18,82 & 13,09 \\
\hline
\end{tabular}

Berdasarkan data pada tabel di atas, data hasil belajar PKn kelompok eksperimen disajikan dalam bentuk kurva polygon, seperti gambar 1 .

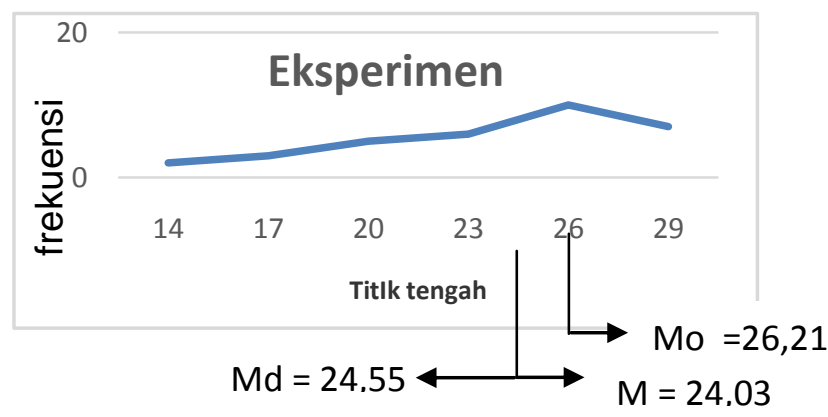

Gambar 1. Kurva Poligon DataHasil Belajar Kelompok Eksperimen 
Berdasarkan kurva tersebut, tampak bahwa sebaran data kelompok siswa yang mengikuti model Talking Stick merupakan kurva juling negatif karena Mo > Md > M $(26,21>24,55>24,03)$. Hal ini menunjukkan bahwa sebagian besar skor siswa kelompok eksperimen cenderung tinggi. Kecenderungan skor ini dapat dibuktikan dengan melihat frekuensi relatif pada tabel distribusi frekuensi. Frekuensi relatif skor yang berada di atas rata-rata lebih besar dibandingkan frekuensi relatif skor yang berada di bawah rata-rata.Sedangkan data hasil belajar siswa kelas kontrol disajikan pada gambar 2.

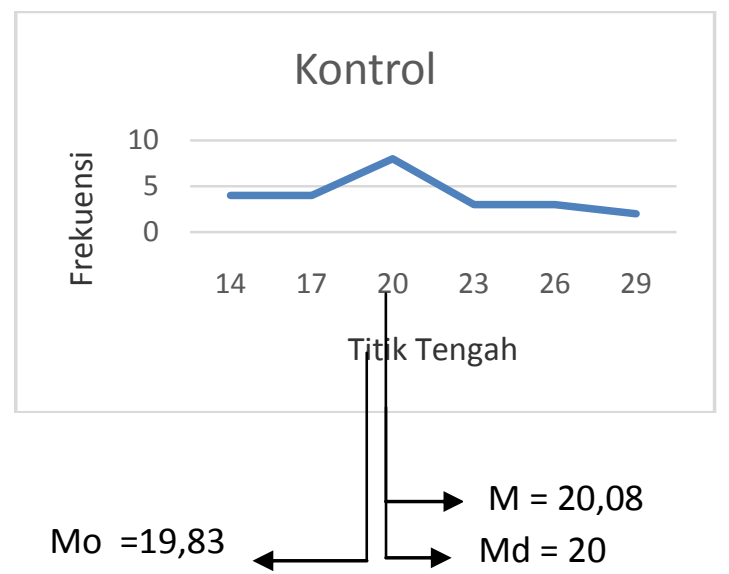

Gambar 2. Kurva Poligon Data Hasil Belajar Kelompok Kontrol

Kurva di atas menunjukkan bahwa kurva sebaran data kelompok siswa yang mengikuti pembelajaran konvensional berupa kurva juling positif karena Mo $<\mathrm{Md}<\mathrm{M}$ $(19,83<20<20,08)$. Hal ini menunjukkan bahwa sebagian besar skor siswa kelompok kontrol cenderung sedang. Kecenderungan skor ini dapat dibuktikan dengan melihat frekuensi relatif pada tabel distribusi frekuensi. Frekuensi relatif skor yang berada di atas rata-rata lebih kecil dibandingkan frekuensi relatif skor yang berada di bawah rata-rata. Setelah melakukan analisis statistik deskriptif, selanjutnya dilakukan uji prasyarat untuk menguji hipotesis. Uji prasyarat yang dilakukan adalah uji normalitas dan homogenitas. Uji normalitas data dilakukan terhadap data hasil belajar PKn kelompok eksperimen dan kontrol. Berdasarkan analisis data yang dilakukan, dapat disajikan hasil uji normalitas sebaran data hasil belajar PKn kelompok eksperimen dan kontrol pada Tabel 3.

Tabel 3. Hasil Uji Normalitas Sebaran Data Hasil Belajar PKn

\begin{tabular}{ccccc}
\hline No & $\begin{array}{c}\text { Kelompok Data Hasil } \\
\text { belajar PKn }\end{array}$ & $x^{2}$ & Nilai Kritis pada Taraf Signifikansi 5\% & Status \\
\hline 1 & Eksperimen & 6,036 & 7,815 & Normal \\
2 & Kontrol & 3,598 & 7,815 & Normal \\
\hline
\end{tabular}

Kriteria pengujian, jika $x_{\text {hitung }}^{2}$ $<x_{\text {tabel }}^{2}$ dengan taraf signifikansi $5 \%(\mathrm{dk}=5-$ 2 - 1), maka data berdistribusi normal. Berdasarkan hasil perhitungan dengan menggunakan rumus Chi Squre, diperoleh $x_{\text {hitung }}^{2}$ skor hasil belajar PKn siswakelompok eksperimen adalah 6,036, sedangkan

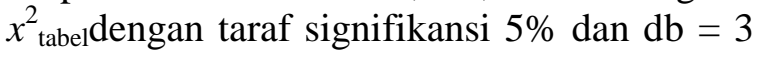

adalah 7,815 . Hal ini berarti, $x^{2}$ hitung skor hasil belajar PKn siswakelompok eksperimen lebih kecil dari $x_{\text {tabel }}^{2}\left(x_{\text {hitung }}^{2}<x_{\text {tabel }}^{2}\right)$, sehingga data hasil belajar PKn siswakelompok eksperimen berdistribusi normal. Selanjutnya, $x_{\text {hitungskor }}^{2}$ hasil belajar PKn siswakelompok kontrol adalah 3,598 dan $x_{\text {tabeldengan taraf }}^{2}$ signifikansi $5 \%$ dan $\mathrm{db}=3$ adalah 7,815 . Hal 
ini berarti, $x^{2}$ hitung data hasil belajar kelompok kontrol lebih kecil dari $x_{\text {tabel }}^{2}\left(x_{\text {hitung }}^{2}<x_{\text {tabel }}^{2}\right)$, sehingga data hasil belajar PKn siswakelompok kontrol berdistribusi normal. Selanjutnya, uji homogenitas dilakukan terhadap varians pasangan antara kelompok eksperimen dan kelompok kontrol. Hasil uji homogenitas varians antara kelompok eksperimen dan kelompok kontrol disajikan pada tabel

Tabel 4. Hasil Uji Homogenitas Kelompok Eksperimen dan Kontrol

\begin{tabular}{lccc}
\hline $\begin{array}{c}\text { Kelompok Data Hasil } \\
\text { belajar PKn }\end{array}$ & F-hitung & F-tabel dengan Taraf Signifikansi 5\% & Status \\
\hline $\begin{array}{l}\text { Eksperimen } \\
\text { Kontrol }\end{array}$ & 1,19 & 2,08 & Homogen \\
\hline
\end{tabular}

Berdasarkan tabel di atas, diketahui $\mathrm{F}_{\text {hitung }}$ skor hasil belajar PKn siswakelompok eksperimen dan kontrol adalah 1,19, sedangkan $F_{\text {tabel }}$ dengan $\mathrm{db}_{\text {pembilang }}=1$ dan $\mathrm{db}_{\text {penyebut }}=43$ pada taraf signifikansi $5 \%$ adalah 2,08. Hal ini berarti, varians data hasil belajar PKn siswakelompok eksperimen dan kontrol adalah homogen. Berdasarkan uji prasyarat analisis data, diperoleh bahwa data hasil post-test kelompok eksperimen dan kelompok kontrol adalah normal dan homogen. Setelah diperoleh hasil dari uji prasyarat analisis data, dilanjutkan dengan pengujian hipotesis penelitian $\left(\mathrm{H}_{1}\right)$ dan hipotesis nol $\left(\mathrm{H}_{0}\right)$. Pengujian hipotesis tersebut dilakukan dengan menggunakan uji-t dengan rumuspolled varians dengan kriteria $\mathrm{H}_{0}$ tolak jika $\mathrm{t}_{\text {hit }}>\mathrm{t}_{\text {tab }}$ dan $\mathrm{H}_{0}$ terima jika $\mathrm{t}_{\text {hit }}<$ $\mathrm{t}_{\text {tab. }}$. Rangkuman hasil perhitungan uji-t antara kelompok eksperimen dan kelompok kontrol disajikan pada tabel 5 .

Tabel 5. Ringkasan Hasil Uji Hipotesis

\begin{tabular}{ccccccc}
\hline Kelompok Data Hasil belajar PKn & Varians & $\mathrm{N}$ & $\mathrm{Db}$ & $\mathrm{t}_{\text {hitung }}$ & $\mathrm{t}_{\text {tabel }}$ & Kesimpulan \\
\hline Kelompok Eksperimen & 18,82 & 25 & \multirow{2}{*}{42} & \multirow{2}{*}{3,048} & \multirow{2}{*}{2,021} & $\mathrm{t}_{\text {hitung }}>\mathrm{t}_{\text {tabel }}$ \\
Kelompok Kontrol & 13,09 & 19 & & & & $\mathrm{H}_{0}$ ditolak \\
\hline
\end{tabular}

Berdasarkan tabel 5, tampak bahwa $t_{\text {hitung }}$ sebesar 3,048, sedangkan, $t_{\text {tabel }}$ dengan $\mathrm{db}=42$ pada taraf signifikansi $5 \%$ adalah 2,021 . Hal ini berarti, $t_{\text {hitung }}$ lebih besar dari $t_{\text {tabel }}\left(t_{\text {hitung }}>t_{\text {tabel }}\right)$ sehingga $\mathrm{H}_{0}$ ditolak dan $\mathrm{H}_{1}$ diterima. Dengan demikian, dapat diinterpretasikan bahwa terdapat perbedaan yang signifikan pada hasil belajar PKn antara siswa yang belajar dengan model Talking Stick dan siswa yang belajar dengan pembelajaran konvensional pada siswa kelas V SD di Gugus I Kecamatan Gerokgak Tahun Pelajaran 2017/2018.

\section{PEMBAHASAN}

Pada bagian pembahasan ini, dipaparkan mengenai perbedaan hasil belajar PKn antara siswa yang dibelajarkan dengan model Talking Stick dan siswa yang dibelajarkan dengan pembelajaran konvensional pada siswa kelas V semester II SD di Gugus I Kecamatan Gerokgak tahun pelajaran 2017/2018. Sampel penelitian adalah siswa kelas V SD Negeri 3 Tukadsumaga sebagai kelas eksperimen dan siswa kelas V SD Negeri 1 Tukadsumaga sebagai kelas kontrol.

Hasil analisis data hasil belajar PKn menunjukan bahwa terdapat perbedaan hasil belajar Pkn antara siswa yang dibelajarkan dengan model Talking Stick dengan siswa yang dibelajarkan dengan pembelajaran konvensional. Tinjauan ini didasarkan pada rata-rata skor dan kecenderungan skor hasil belajar PKn yang diperoleh kedua kelompok. Rata-rata skor hasil belajar PKn siswa kelompok eksperimen adalah 19,26 (kategori tinggi), sedangkan rata-rata skor hasil belajar PKn siswa kelompok kontrol adalah 16,83 (kategori sedang). Begitu pula yang tampak 
pada kurva poligon, sebaran data kelompok ini merupakan juling negatif. Artinya, sebagian besar skor siswa cenderung tinggi. Namun berbeda halnya pada kelompok kontrol, kurva sebaran data merupakan juling positif, yang artinya sebagian besar skor siswa cenderung rendah.

Selain dilihat dari nilai rata-rata tersebut, dapat dilihat berdasarkan analisis data menggunakan uji-t, diketahui $t_{\text {hitung }}=$ 2,025 dan $t_{\text {tabel }}(\mathrm{dk}=50$ pada taraf signifikansi $5 \%)=2,0$. Hasil perhitungan tersebut menunjukkan bahwa $t_{\text {hitung }}$ lebih besar dari $t_{\text {tabel }}$ $\left(t_{\text {hitung }}>t_{\text {tabel }}\right)$, sehingga hasil penelitian adalah signifikan. Hal ini berarti, terdapat perbedaan yang signifikan pada hasil belajar PKn antara siswa yang belajar dengan model Talking Stick dan siswa yang belajar dengan pembelajaran konvensional.

Perbedaan yang signifikan hasil belajar PKn antara kelompok siswa yang dibelajarkan menggunakan model Talking Stick dengan kelompok siswa yang dibelajarkan menggunakan pembelajaran konvensional disebabkan oleh beberapa faktor yaitu adanya perlakukan perbedaan langkah-langkah pembelajaran. Siswa lebih memahami materi yang diajarkan, karena dalam kegiatan pembelajaran dengan menggunakan model ini mau tidak mau semua siswa harus menanggapi satu pertanyaan yang telah disiapkan oleh guru. Hal ini sesuai dengan pendapat (Shoimin, 2014:199) Kelebihan model talking stick yaitu menguji kesiapan peserta didik dalam pembelajaran, melatih peserta didik memahami materi dengan cepat, memacu agar peserta didik lebih giat belajar (belajar dahulu sebelum pelajaran dimulai), dan peserta didik berani mengemukakan pendapat.

Berdasarkan perlakuan yang diberikan pada pembelajaran, siswa kelompok eksperimen yaitu pada saat pembelajaran terlihat siswa lebih aktif berpendapat mengenai materi, siswa berani berbicara di kelas lebih memahami materi yang diajarkan.

Sedangkan hasil pembelajaran pada kelompok kontrol dengan menggunakan pembelajaran konvensional tergolong cukup, karena terlihat pembelajaran masih didominasi oleh guru dari awal sampai akhir pembelajaran berlangsung sehingga membuat siswa menjadi pasif dan kurang aktif dalam pembelajaran. Hal ini sesuai dengan pendapat Rasana (2009:21) yang menyatakan pembelajaran konvensional merupakan sebuah model pembelajaran yang ditandai dengan penyajian-penyajian pengalaman yang berkaitan dengan konsep yang akan dipelajari, dilanjutkan dengan pemberian informasi oleh guru, tanya jawab, pemberian tugas oleh guru, pelaksanaan tugas oleh siswa sampai pada akhirnya guru merasa bahwa apa yang telah diajarkan dimengerti oleh siswa.

Perbedaan cara pembelajaran antara siswa yang dibelajarkan menggunakan model Talking Stick dengan siswa yang dibelajarkan menggunakan pembelajaran konvensional tentunya memberikan dampak yang berbeda terhadap hasil belajar siswa.

Hasil penelitian ini juga diperkuat oleh temuan hasil penelitian sebelumnya yang dilakukan oleh Pradnyani (2013). Dalam penelitiannya tersebut, dibuktikan bahwa hasil belajar IPS siswa yang mengikuti pembelajaran dengan menggunakan Model Pembelajaran Kooperatif Tipe Talking Stickdapat meningkatkan hasil belajar siswa. Penelitian serupa juga dilakukan oleh (Anggarini, 2013), yang berjudul "Pengaruh Model Pembelajaran Kooperatif Talking Stick Berbasis Aneka Sumber Terhadap Hasil Belajar IPS Siswa Kelas V Sd Negeri 5 Dalung". Dalam penelitian tersebut dibuktikan bahwa model pembelajaran kooperatif Talking Stick berbasis aneka sumber dapat meningkatkan hasil belajar.

Penelitian yang dilakukan oleh Puspitasari (2013), yang berjudul Pengaruh Strategi Pembelajaran $\mathrm{Pq} 4 \mathrm{r}$ Dan Motivasi Belajar Terhadap Hasil Belajar Pkn Siswa Kelas Iv SD Gugus 2 Tampaksiring. Hasil penelitian tersebut menunjukan peningkatan hasil belajar PKn

Penelitian yang dilakukan oleh Partini (2013), yang berjudul "Pengaruh Model Pembelajaran Terpadu Connected Terhadap Hasil Belajar PKn Siswa Kelas IV Sd N 28 Dangin Puri". Hasil penelitian ini menunjukan peningkatan hasil belajar PKn.

Penelitian yang dilakukan oleh Darmawati (2013), yang berjudul "Pengaruh 
Model Pembelajaran Children Learning In Science Berbantuan Metode Talking Stick Terhadap Sikap Ilmiah Dan Penguasaan Konsep IPA Kelas V". Hasil penelitian ini dapat meningkatkan sikap ilmiah dan penguasaan konsep IPA.Penelitian yang dilakukan oleh (Valentina, 2013), yang berjudul "Pengaruh Model Pembelajaran Time Token Arends Terhadap Hasil Belajar PKn Siswa Kelas V SD Gugus Ii Kecamatan Seririt". Hasil penelitian ini menunjukan peningkatan hasil belajar siswa.

Berdasarkan pemaparan di atas, maka dapat disimpulkan bahwa terdapat perbedaan yang signifikan hasil belajar PKn antara siswa yang dibelajarkan menggunakan model Talking Stick dengan siswa yang dibelajarkan menggunakan pembelajaran konvensional pada siswa kelas V SD di Gugus I Kecamatan Gerokgak tahun pelajaran 2017/2018.

\section{SIMPULAN DAN SARAN}

Berdasarkan hasil penelitian dan pembahasan, dapat disimpulkan bahwa terdapat perbedaan yang signifikan hasil belajar PKn antara siswa yang dibelajarkan dengan model Talking Stick dan siswa yang dibelajarkan dengan pembelajaran konvensional pada siswa kelas V semester II SD di Gugus I Kecamatan Gerokgak tahun pelajaran 2017/2018. Hal tersebut diperoleh dari hasil perhitungan uji-t, $t_{\text {hitung }}$ adalah 3,048, sedangkan $\mathrm{t}_{\text {tabel }}$ pada taraf signifikasi $5 \%$ dan $\mathrm{db}=42$ adalah 2,021. Hal ini berarti $t_{\text {hitung }}$ lebih besar dari $t_{\text {tabel }}\left(t_{\text {hitung }}>t_{\text {tabel }}\right)$. Disamping itu, rata-rata skor hasil belajar PKn siswa yang belajar dengan model Talking Stick $(23,08)$ lebih tinggi dari siswa yang dibelajarkan dengan pembelajaran konvensional $(19,26)$. Dengan demikian, model model Talking Stick berpengaruh terhadap hasil belajar PKn pada siswa kelas V Semester II di Gugus I Kecamatan Gerokgak Tahun Pelajaran 2017/2018. Saran-saran yang dapat disampaikan berdasarkan penelitian yang telah dilakukan adalah 1) Disarankan kepada siswa agar lebih memotivasi diri dan lebih aktif dalam mengikuti pembelajaran yang diberikan guru, sehingga dapat meningkatkan hasil belajar pada setiap mata pelajaran. 2)
Disarankan kepada guru agar lebih berinovasi dalam pembelajaran dan menerapakan model Talking Stickkarena hasil penelitian membuktikan bahwa penggunaan model Talking Stickmampu meningkatkan hasil belajar serta motivasi berprestasi siswa. 3) Disarankan kepada kepala sekolah agar dapat menggunakan hasil penelitian ini sebagai bahan acuan pedoman untuk membimbing guru-guru dalam melaksanakan pembelajaran dengan menggunakan model pembelajaran untuk meningkatkan hasil belajar dan motivasi berprestasi siswa. 4) Disarankan kepada peneliti lain agar hasil penelitian ini dapat digunakan sebagai acuan kepustakaan untuk melakukan penelitian dalam variabel yang sama ataupun pada variabel yang berbeda.

\section{DAFTAR RUJUKAN}

Anggarini, D. 2013. "Pengaruh Model Pebelajaran Kooperatif Talking Stick Berbasis Aneka Sumber Terhadap Hasil Belajar Ips Siswa Kelas V Sd Negeri 5Dalung". Tersedia pada https://ejournal.undiksha.ac.id/index.p hp/JJPGSD/article/view/1440/1301 (diakses tanggal 8 Januari 2018).

Darmawati, A. 2013. "Pengaruh Model Pembelajaran Children Learning In Science Berbantuan Metode Talking Stick TerhadapSikap Ilmiah Dan Penguasaan Konsep IPA Kelas V'. Tersedia pada https://ejournal.undiksha.ac.id/index.p hp/JJPGSD/article/view/789 (diakses tanggal 4 Juni 2018).

Depdiknas. 2003. Undang-Undang No. 20 Tahun 2003 tentang Sistem Pendidikan Nasional, Jakarta: Depdiknas.

Partini, Kd. 2013. Pengaruh Model Pembelajaran Terpadu Connected Terhadap Hasil Belajar PKn Siswa Kelas IVSd N 28 Dangin Puri.Tersedia pada

https://ejournal.undiksha.ac.id/index.p hp/JJPGSD/article/view/775 (diakses tanggal 04 Juni 2018).

Pradnyani, D. 2013. Pengaruh Penerapan Model Pembelajaran Kooperatif Tipe 
Talking Stick Terhadap Hasil Belajar Ips Siswa Kelas 4 Sdn 2 Sesetan Denpasar. Tersedia pada https://ejournal.undiksha.ac.id/index.p hp/JJPGSD/article/view/957/827 (diakses tanggal 8 Januari 2018).

Puspitasari. Eka. 2013. Pengaruh Strategi Pembelajaran Pq4r Dan Motivasi Belajar Terhadap Hasil Belajar PKn Siswa Kelas IV SD Gugus 2 Tampaksiring. Tersedia pada https://ejournal.undiksha.ac.id/index.p hp/JJPGSD/article/view/1193 (diakses tanggal 4 Juni 2018).

Shoimin. Aris. 2014. 68 Model Pembelajaran
Inovatif dalam Kurikulum 2013. Yogyakarta: Ar-Ruzz Media.

Rasana, Raka. 2009. Model-Model Pembelajaran. Singaraja: Undiksha.

Valentina. F. 2013. "Pengaruh Model Pembelajaran Time Token ArendsTerhadap Hasil Belajar Pkn Siswa Kelas $V$ SD Gugus Ii Kecamatan Seririt". Tersedia pada https://ejournal.undiksha.ac.id/index.p $\mathrm{hp/JJPGSD/article/view/835} \mathrm{(diakses}$ tanggal 9 Januari 2018). 